\title{
Rural medical student opinions about rural practice: does choice of college make a difference?
}

\author{
William J. Crump, MD', Craig H. Ziegler PhD, MA², \\ R. Steve Fricker, MPA ${ }^{1}$
}



PuRPose: While many programs assume medical students who attended rural colleges are more likely to practice in smaller towns later, there are few studies to support this assumption. This study examines aspects of medical students' opinions about rural living and rural practice based on where they attended college.

METHOD: Students with rural upbringing were identified and administered a previously published rural health opinion survey. The opinion survey was administered across three academic years, from 2015 to 2017, and included a total of three scales and nine subscales for analysis. Factor analysis was used to identify the nine subscales.
Author affiliations are listed at the end of this article.

Correspondence to: William J. Crump, MD University of Louisville School of Medicine at Baptist Health bill.crump@bhsi.com

RESULTS: Respondents who attended small town colleges tended to have much stronger opinions about the positive aspects of small town living. Small town college attendees also had stronger positive opinions regarding rural practice than their larger college counterparts.

DIscussION: These preliminary data indicate considering a medical school applicants' choice of college may provide insight into their opinions about future rural practice. Additional research is needed to collect a larger dataset to examine the association of college choice with opinions about rural practice.

\section{KEYWORDS}

Rural Medical Education, Practice Site Choice, Medical Students

\section{INTRODUCTION}

Physician maldistribution remains an important problem in the United States. Medical schools that have as part of their mission the task of producing physicians for small towns need useful markers when selecting students.

A recent review found twenty-two high quality studies that proved that students from rural backgrounds were more likely to choose rural practice. ${ }^{1}$ Participating in a focused rural training program was also found to be a strong predictor of later rural practice, as was choice of Family Medicine as a specialty. Demographics including gender, marital status, and international medical graduate's status were of minimal effect. The ability to have a broader scope of practice and student loan repayment programs also showed a very small effect.

While rural upbringing is the strongest predictor, well over half of rural medical students will choose urban or suburban practice. Rural tracks and focused training programs are limited in size, and cannot include all rural students. The focus of this study was to examine aspects of premedical rural students that may show positive opinions about eventual rural practice.

While many focused rural programs do assume that 
students who graduated from small rural colleges may be more likely to choose a rural practice, there are very few supporting studies. ${ }^{2}$ Here we examine specifically whether attendance at a college in a small town is associated with more positive opinions about rural living and practice among rural incoming medical students.

\section{METHODS}

\section{Study Design}

Using a previously published rural health opinion survey (RHOS), ${ }^{3}$ we asked all students with rural upbringing at the beginning of medical school across three academic years from 2015-2017 to give their opinions on forty one items concerning rural living, rural patients, and rural medical practice. Across the three years of data collection, the response rate was $69 \%$ (59/86).

Based on a large previous study in this medical school where internal consistency and reliability were described and Cronbach's alphas ranged from .58 to .82 , nine factors were developed that grouped the forty one questions into three areas including opinions about rural areas, rural patients, and rural physician practice (Table 1 ). ${ }^{4}$ 4=Agree, $5=$ Strongly Agree

\begin{tabular}{|c|c|c|}
\hline In Rural Areas: & Patients in Rural Areas: & Physicians in Rural Areas: \\
\hline Comfortable Living & Patient Motivation & Medical Resources \\
\hline $\begin{array}{l}\text { The physical environment is } \\
\text { clean }\end{array}$ & $\begin{array}{l}\text { Are interested in preventive } \\
\text { health care }\end{array}$ & $\begin{array}{l}\text { Have opportunities for } \\
\text { professional interaction }\end{array}$ \\
\hline $\begin{array}{l}\text { There are opportunities for a } \\
\text { relaxed } \\
\text { lifestyle }\end{array}$ & $\begin{array}{l}\text { Are interested in learning about } \\
\text { their medical conditions }\end{array}$ & $\begin{array}{l}\text { Have access to medical } \\
\text { consultants }\end{array}$ \\
\hline $\begin{array}{l}\text { The rate of homicide is lower } \\
\text { than the } \\
\text { national average rate of } \\
\text { homicide }\end{array}$ & $\begin{array}{l}\text { Are interested in maintaining } \\
\text { their health }\end{array}$ & $\begin{array}{l}\text { Have access to advanced } \\
\text { medical technology }\end{array}$ \\
\hline $\begin{array}{l}\text { The police are willing to } \\
\text { provide } \\
\text { assistance }\end{array}$ & Follow their physician's advice & Have competent support staff \\
\hline $\begin{array}{l}\text { The cost of living is lower than } \\
\text { the } \\
\text { national average cost of living }\end{array}$ & $\begin{array}{l}\text { Are willing to try new } \\
\text { treatments }\end{array}$ & $\begin{array}{l}\text { Have access to continuing } \\
\text { medical education }\end{array}$ \\
\hline $\begin{array}{l}\text { Comfortable houses are } \\
\text { available }\end{array}$ & Physician Value & $\begin{array}{l}\text { Can easily schedule vacation } \\
\text { time }\end{array}$ \\
\hline $\begin{array}{l}\text { There are opportunities to } \\
\text { pursue leisure } \\
\text { activities }\end{array}$ & $\begin{array}{l}\text { Want to have the same } \\
\text { physician over time }\end{array}$ & Have hospital privileges \\
\hline $\begin{array}{l}\text { Availability of Quality } \\
\text { Services }\end{array}$ & Trust their physicians & Physician Workload \\
\hline $\begin{array}{l}\text { Health care services are } \\
\text { available }\end{array}$ & $\begin{array}{l}\text { View physicians as an } \\
\text { important part of their } \\
\text { community }\end{array}$ & Work more hours per week \\
\hline $\begin{array}{l}\text { Day Care services for children } \\
\text { are } \\
\text { available }\end{array}$ & $\begin{array}{l}\text { Keep appointments with their } \\
\text { physicians }\end{array}$ & See more patients daily \\
\hline $\begin{array}{l}\text { There are employment } \\
\text { opportunities }\end{array}$ & & $\begin{array}{l}\text { Are often contacted by patients } \\
\text { after regular hours }\end{array}$ \\
\hline $\begin{array}{l}\text { The schools provide quality } \\
\text { education }\end{array}$ & & Are often on call \\
\hline Community Support & & Have to do more paperwork \\
\hline \multicolumn{3}{|l|}{$\begin{array}{l}\text { There are friendly people in } \\
\text { the } \\
\text { community }\end{array}$} \\
\hline \multirow{10}{*}{$\begin{array}{l}\text { Neighbors help each other } \\
\text { There are opportunities to } \\
\text { participate in } \\
\text { community activities }\end{array}$} & & \\
\hline & & $\begin{array}{l}\text { Physician Status in the } \\
\text { Community }\end{array}$ \\
\hline & & $\begin{array}{l}\text { Know most people in their } \\
\text { communities }\end{array}$ \\
\hline & & $\begin{array}{l}\text { Are respected by their } \\
\text { communities }\end{array}$ \\
\hline & & $\begin{array}{l}\text { Are expected to be involved in } \\
\text { the community }\end{array}$ \\
\hline & & $\begin{array}{l}\text { Are responsible for helping } \\
\text { with social problems }\end{array}$ \\
\hline & & Attractive Practice Options \\
\hline & & Have employment opportunities \\
\hline & & $\begin{array}{l}\text { Earn incomes within the } \\
\text { national average }\end{array}$ \\
\hline & & Have comfortable offices \\
\hline
\end{tabular}

All items have Likert response formats: 1= Strongly Disagree, 2=Disagree, 3=Neither agree or Disagree,

TABLE 1: RHOS subscales and items. 
A designation whether the student was rural or not was defined as the location of the high school attended in the Rural Urban Continuum Code ${ }^{5}$ (RUCC) category $>3$ (non-metropolitan), as well as the town hosting the high school being less than 30,000 . The same definition was used to define whether the college attended was rural or not.

The results of the survey were transferred from the survey instrument to Microsoft Excel Version 2010 (Microsoft, Redmond, WA) and then to SPSS Version 25.0 (IBM Corp, Armonk, NY) for statistical analyses. Pearson's Chi-Square, independent sample t-test, along with Cohen's D were performed to analyze the data. Cohen's $D$ is considered a measure of effect size, with $>.20$ being considered small effect size, $>.50$ being medium effect size and $>.80$ considered a large effect size.6 The University of Louisville School of Medicine Institutional Review Board approved this expedited study, Medical Student Opinions of Rural Health, on June 14, 2016, reference number: 576360 .

\begin{tabular}{|c|c|c|c|c|c|c|}
\hline & & \multicolumn{2}{|c|}{ Rural College } & \multicolumn{2}{|c|}{ Not rural college } & \multirow[b]{2}{*}{ P value } \\
\hline & & Freq & $(\%)$ & Freq & $(\%)$ & \\
\hline \multirow{2}{*}{ Gender ${ }^{a}$} & Female & 8 & $(25 \%)$ & 24 & $(75 \%)$ & 0.690 \\
\hline & Male & 8 & $(30 \%)$ & 19 & $(70 \%)$ & \\
\hline \multirow[t]{3}{*}{ Race $^{a}$} & White & 14 & $(26 \%)$ & 39 & $(74 \%)$ & 0.772 \\
\hline & Black & 1 & $(50 \%)$ & 1 & $(50 \%)$ & \\
\hline & Other & 1 & $(25 \%)$ & 3 & $(75 \%)$ & \\
\hline
\end{tabular}

${ }^{a}$ Percentages are based on percent within gender and race

TABLE 3: Demographic Descriptors by Site of College

\section{RESULTS}

The demographics on the responders and nonresponders are shown in Table 2; the demographics of the respondents divided by whether or not they attended a small town college are shown in Table 3.

The results for the nine factors are shown in Table 4. The differences in opinions from the two groups were very close to statistical significance for the total rural areas score and the Cohen's D showed a medium effect size. Each sub component of this category also had notable effect sizes. The category of opinions about rural patients showed a negligible effect size, as did each of the two subcomponents. Effect sizes for the rural physicians components were also notable, except for attractive practice options, which showed very little difference between the two groups.

\section{DISCUSSION}

Admissions committees at medical schools that have a mission to produce more rural physicians need reliable ways to make this prediction. We found only one study that showed the separate effect of attendance at a small town college. ${ }^{2}$

In a previous publication from this medical school population, we found that six times as many students chose rural practice if they attended our rural medical school campus, three times as many chose rural practice if they had rural upbringing, and five times as many chose rural practice if they also chose a family medicine residency. ${ }^{7}$ But $85 \%$ of those with rural upbringing did not choose rural practice. Choice of a rural college may help predict some of this attrition. 


\begin{tabular}{|c|c|c|c|c|c|c|}
\hline & $\begin{array}{l}\text { Undergraduate } \\
\text { College Location }\end{array}$ & $\mathrm{N}$ & Mean & $\begin{array}{c}\text { Std. } \\
\text { Deviation }\end{array}$ & $\begin{array}{l}\text { Cohen's } \\
\text { D } \\
\text { (Effect } \\
\text { Size) }\end{array}$ & P-Value \\
\hline \multirow[t]{2}{*}{ Total rural areas score } & Rural & 16 & 4.25 & $(0.33)$ & 0.59 & 0.054 \\
\hline & Non-Rural & 43 & 4.03 & $(0.41)$ & & \\
\hline \multirow[t]{2}{*}{ Comfortable Living } & Rural & 16 & 4.31 & $(0.43)$ & 0.46 & 0.123 \\
\hline & Non-Rural & 43 & 4.10 & $(0.48)$ & & \\
\hline \multirow{2}{*}{$\begin{array}{l}\text { Availability of Quality } \\
\text { Services }\end{array}$} & Rural & 16 & 3.80 & $(0.43)$ & 0.51 & 0.119 \\
\hline & Non-Rural & 43 & 3.51 & $(0.68)$ & & \\
\hline \multirow[t]{2}{*}{ Community Support } & Rural & 16 & 4.73 & $(0.41)$ & 0.39 & 0.204 \\
\hline & Non-Rural & 43 & 4.56 & $(0.47)$ & & \\
\hline \multirow[t]{2}{*}{ Total rural patients score } & Rural & 16 & 3.74 & $(0.57)$ & 0.09 & 0.721 \\
\hline & Non-Rural & 43 & 3.69 & $(0.52)$ & & \\
\hline \multirow[t]{2}{*}{ Patient Motivation } & Rural & 16 & 3.35 & $(0.65)$ & 0.15 & 0.599 \\
\hline & Non-Rural & 43 & 3.25 & $(0.68)$ & & \\
\hline \multirow[t]{2}{*}{ Physician Value } & Rural & 16 & 4.23 & $(0.54)$ & 0.02 & 0.978 \\
\hline & Non-Rural & 43 & 4.24 & $(0.48)$ & & \\
\hline \multirow{2}{*}{$\begin{array}{l}\text { Total rural physicians } \\
\text { score }\end{array}$} & Rural & 16 & 3.54 & $(0.27)$ & 0.17 & 0.627 \\
\hline & Non-Rural & 43 & 3.49 & $(0.32)$ & & \\
\hline \multirow[t]{2}{*}{ Medical Resources } & Rural & 16 & 3.65 & $(0.58)$ & 0.27 & 0.349 \\
\hline & Non-Rural & 43 & 3.50 & $(0.53)$ & & \\
\hline \multirow{2}{*}{$\begin{array}{l}\text { Physician Status } \\
\text { Within } \\
\text { Community }\end{array}$} & Rural & 16 & 4.39 & $(0.48)$ & 0.37 & 0.212 \\
\hline & Non-Rural & 43 & 4.22 & $(0.45)$ & & \\
\hline \multirow[t]{2}{*}{ Physician Workload } & Rural & 16 & 3.64 & $(0.57)$ & 0.30 & 0.292 \\
\hline & Non-Rural & 43 & 3.47 & $(0.55)$ & & \\
\hline \multirow{2}{*}{$\begin{array}{l}\text { Attractive Practice } \\
\text { Options }\end{array}$} & Rural & 16 & 4.08 & $(0.69)$ & 0.02 & 0.957 \\
\hline & Non-Rural & 43 & 4.09 & $(0.59)$ & & \\
\hline
\end{tabular}

aScales range from 1 to 5 with higher scores indicating more favorable opinions for all but one scale



TABLE 4: Comparison of Rural versus Non-rural College Location on the RHOS Scales and Subscales ${ }^{\mathrm{a}}$ 
Using standard $p$ values with Likert scale data and relatively small groups may be less reliable than looking at the effect size. These results must be considered preliminary but show that students that attended colleges in small towns had more positive opinions about small-town living and positive (though smaller and non-statistically significant) opinions about practice of rural physicians.

It may be that attendance at college would not change opinions about rural patients, as all of the students have been rural patients themselves. Opinions about this cluster of responses would change very little across the four to five years of college. It is interesting though that those who attended small town colleges have stronger opinions about the positive aspects of small town living. The issue of differences of opinion about medical resources being of only medium effect size also may be because the opinions formed about this would be less likely to be changed during the four to five years of college life among these largely healthy students who may not have needed these resources during college.

\section{LIMITATIONS}

The survey results reflect only $69 \%$ of all rural students at this medical school, but for most surveys this is a very high response rate. And women were overrepresented in the respondents. The lack of statistical significance may represent the small size of the groups, but the effect size may be more important for those considering use of these data in medical school admissions.

Although this survey has been used in several different environments and has been felt to be reliable and valid, it has not been in use long enough to prove that opinions predict rural practice. However studies have shown that students' opinions during medical school are reflected well in their choice of ultimate practice site. ${ }^{8}$

Without randomization, it is not possible to differentiate the selection bias by those students with a small town upbringing that chose rural colleges because they already had positive opinions. Choice of a rural college may also be because tuition is less or the campus is closer to their home, and our data does not allow us to differentiate those motivations. This selection bias actually may give an early indicator of small town students that may be useful for admissions committees. This "voting with your feet" may be more powerful than simply saying in an interview that you intend to practice in a small town. Our regional campus dean (WJC) has a standing annual invitation to speak to the pre-professional clubs at two nearby regional universities, and we continue to collect opinion data as part of those presentations to look more carefully at the opinions and motivations of premedical students attending smaller regional college campuses.

We also continue the annual survey, building a longitudinal database by collecting this kind of information each year from medical students at both the urban and our regional rural campuses. We continue to look closely at opinions that the students have concerning these nine categories of factors. The time rural students spend in an urban medical school environment can potentially cause "urban disruption" of their rural sensibilities. ${ }^{4}$ Once these students have completed residency training and chosen a practice site, we will study the association of student opinions with subsequent practice site. We welcome collaborators and can share the survey instrument with colleagues at other campuses.

\section{AUTHOR AFFILIATIONS}

1. University of Louisville School of Medicine at Baptist Health, Madisonville, Kentucky

2. University of Louisville School of Medicine, Louisville, Kentucky

\section{REFERENCES}

1. MacQueen IT, Maggard-Gibbons M, Capra $\mathrm{G}$, Raeen $\mathrm{L}$, et al. Recruiting rural healthcare providers today: a systematic review of training program success and determinants of geographic choices. J Gen Intern Med. 2018;33(2):191-9.

2. Jarman BT, Cogbill, $\mathrm{TH}$, Mathiason, $\mathrm{AM}, \mathrm{O}$ 'Heron, T. Factors correlated with surgery resident choice 
to practice general surgery in a rural area. J Surg. 2009;66:319-24.

3. Lynch DC, Willis SE. Can a 3-day preceptorship change first-year medical students' opinions about living and working in small towns? Fam Med. 2000;32(7):495-500.

4. Crump WJ, Ziegler CH, Martin LJ, Fricker RS, Shaw MA, Crump AM, Sawning S. Changes in rural affinity among rural medical students as they experience education in an urban setting. Marshall Journal of Medicine. 2017;3(1):57-71.

5. United States Department of Agriculture. Economic Research Service. Rural-Urban Continuum Codes. Available at: http://www.ers. usda.gov/data-products/rural-urban-continuumcodes.aspx. Accessed February 6, 2018.

6. Cohen J. Statistical power analysis for the behavioral sciences (2nd ed.). Hillsdale, NJ: Lawrence Earlbaum Associates; 1988.

7. Crump WJ, Fricker RS, Ziegler $\mathrm{CH}$, Wiegman DL. Increasing the rural physician workforce: a potential role for small rural medical school campuses. J Rural Health. 2016;32(3):254-9.

8. Shannon CK, Jackson J. Validity of medical student questionnaire data in prediction of rural practice choice and its association with service orientation. J Rural Health. 2015;31(4):373-81. 